\title{
BAMBI (Bone Morphogenetic Protein and Activin Membrane-Bound Inhibitor) Reveals the Involvement of the Transforming Growth Factor- $\beta$ Family in Pain Modulation
}

\author{
Mónica Tramullas, ${ }^{1,2}$ Aquilino Lantero, ${ }^{1,2}$ Álvaro Díaz, ${ }^{1,3,4}$ Néstor Morchón, ${ }^{1}$ David Merino, ${ }^{1,2}$ Ana Villar, ${ }^{1,2}$ \\ Dirk Buscher, ${ }^{6}$ Ramón Merino, ${ }^{1,2,3}$ Juan M. Hurlé, ${ }^{1,2}$ Juan Carlos Izpisúa-Belmonte, ${ }^{5,6}$ and María A. Hurlé ${ }^{1,2}$ \\ ${ }^{1}$ Facultad de Medicina, Universidad de Cantabria, 39011 Santander, Spain, ${ }^{2}$ Instituto de Formación e Investigación Marqués de Valdecilla, 39008 \\ Santander, Spain, ${ }^{3}$ Instituto de Biomedicina y Biotecnología de Cantabria, 39011 Santander, Spain, ${ }^{4}$ Centro de Investigación Biomédica en Red de Salud \\ Mental, 39011 Santander, Spain, ${ }^{5}$ Centro de Medicina Regenerativa de Barcelona, 08003 Barcelona, Spain, and ${ }^{6}$ Salk Institute for Biological Studies, La Jolla, \\ California 92037
}

Transforming growth factors- $\beta$ (TGF- $\beta$ s) signal through type I and type II serine-threonine kinase receptor complexes. During ligand binding, type II receptors recruit and phosphorylate type I receptors, triggering downstream signaling. BAMBI [bone morphogenetic protein (BMP) and activin membrane-bound inhibitor] is a transmembrane pseudoreceptor structurally similar to type I receptors but lacks the intracellular kinase domain. BAMBI modulates negatively pan-TGF- $\beta$ family signaling; therefore, it can be used as an instrument for unraveling the roles of these cytokines in the adult CNS. BAMBI is expressed in regions of the CNS involved in pain transmission and modulation. The lack of $B A M B I$ in mutant mice resulted in increased levels of TGF- $\beta$ signaling activity, which was associated with attenuation of acute pain behaviors, regardless of the modality of the stimuli (thermal, mechanical, chemical/inflammatory). The nociceptive hyposensitivity exhibited by $B A M B I^{-1-}$ mice was reversed by the opioid antagonist naloxone. Moreover, in a model of chronic neuropathic pain, the allodynic responses of $B A M B I^{-1-}$ mice also appeared attenuated through a mechanism involving $\delta$-opioid receptor signaling. Basal mRNA and protein levels of precursor proteins of the endogenous opioid peptides proopiomelanocortin (POMC) and proenkephalin (PENK) appeared increased in the spinal cords of $B A M B I^{-1-}$. Transcript levels of TGF- $\beta$ s and their intracellular effectors correlated directly with genes encoding opioid peptides, whereas $B A M B I$ correlated inversely. Furthermore, incubation of spinal cord explants with activin A or BMP-7 increased POMC and/or PENK mRNA levels. Our findings identify TGF- $\beta$ family members as modulators of acute and chronic pain perception through the transcriptional regulation of genes encoding the endogenous opioids.

\section{Introduction}

The transforming growth factor- $\beta$ (TGF- $\beta$ ) superfamily of cytokines includes activins, TGF- $\beta$ s, and bone morphogenetic proteins (BMPs). TGF- $\beta$ s signal through heteromeric combinations of type I receptors, also termed activin-like kinases (ALK), and type II receptors, both of which are serine/threonine kinases (Wrana et al., 1994). Ligand binding leads to downstream propagation of the signal through canonical phosphorylation of Smad proteins, which are translocated into the nucleus to regulate the transcription of TGF- $\beta$ target genes (Feng and Derynck, 2005; Massagué et al., 2005), as well as through noncanonical signaling, notably via TGF- $\beta$-activated kinase 1 (TAK1) (Yamaguchi et al.,

Received June 2, 2009; revised Dec. 3, 2009; accepted Dec. 8, 2009.

This work was supported by Ministerio de Ciencia e Innovación Grant SAF2007-65451, Instituto de Salud Carlos III Grant RD06/0001/1016, and Fundació La Marató de TV3 Grant 072131 (M.A.H.), by Instituto de Salud Carlos III Grant FIS-PI 060240, by Ministerio de Ciencia e Innovación Grant SAF2005-00811 (R.M.), and by the National Institutes of Health and the G. Harold and Leila Y. Mathers Charitable Foundation (J.C.I.-B.). We thank N. García, S. Pérez, M. F. Calderón, and C. Badía for their technical assistance.

Correspondence should be addressed to María A. Hurlé, Departamento Fisiología y Farmacología, Facultad de Medicina, Avda Herrera Oria s/n, 39011 Santander, Spain. E-mail: hurlem@unican.es.

D. Buscher's present address: Cellerix SL, Tres Cantos, 28760 Madrid, Spain.

DOI:10.1523/JNEUROSCI.2584-09.2010

Copyright $\odot 2010$ the authors $\quad 0270-6474 / 10 / 301502-10 \$ 15.00 / 0$
1995; Zhang, 2009). TGF- $\beta$ signaling is modulated by BAMBI (BMP and activin membrane-bound inhibitor), a transmembrane protein that is structurally similar to type I receptors but lacks the intracellular kinase domain. BAMBI acts as a pseudoreceptor that inhibits pan-TGF- $\beta$ family signaling by preventing the formation of active receptor complexes (Onichtchouk et al., 1999; Yan et al., 2009). BAMBI can also function as a positive regulator of the $\mathrm{Wnt} / \beta$-catenin pathway (Lin et al., 2008).

Little is known about the physiological functions regulated by BAMBI or the pathological consequences of an unbalance between BAMBI and TGF- $\beta$ s. During embryogenesis, BAMBI would act as a negative feedback regulator of BMP signaling (Onichtchouk et al., 1999; Tsang et al., 2000), in a context of cooperative function within the BMP-4 synexpression group (Grotewold et al., 2001; Karaulanov et al., 2004). However, deletion of the BAMBI gene has no apparent phenotypic consequences affecting embryonic development (Chen et al., 2007). BAMBI deregulation has been involved in the pathogenesis of various human pathologies, such as tumor progression and metastatic capability (Togo et al., 2008; Fritzmann et al., 2009; Khin et al., 2009), pathological fibrosis (Seki et al., 2007; Harada et al., 2009), and metaplastic bone formation (Kitazawa et al., 2005). 


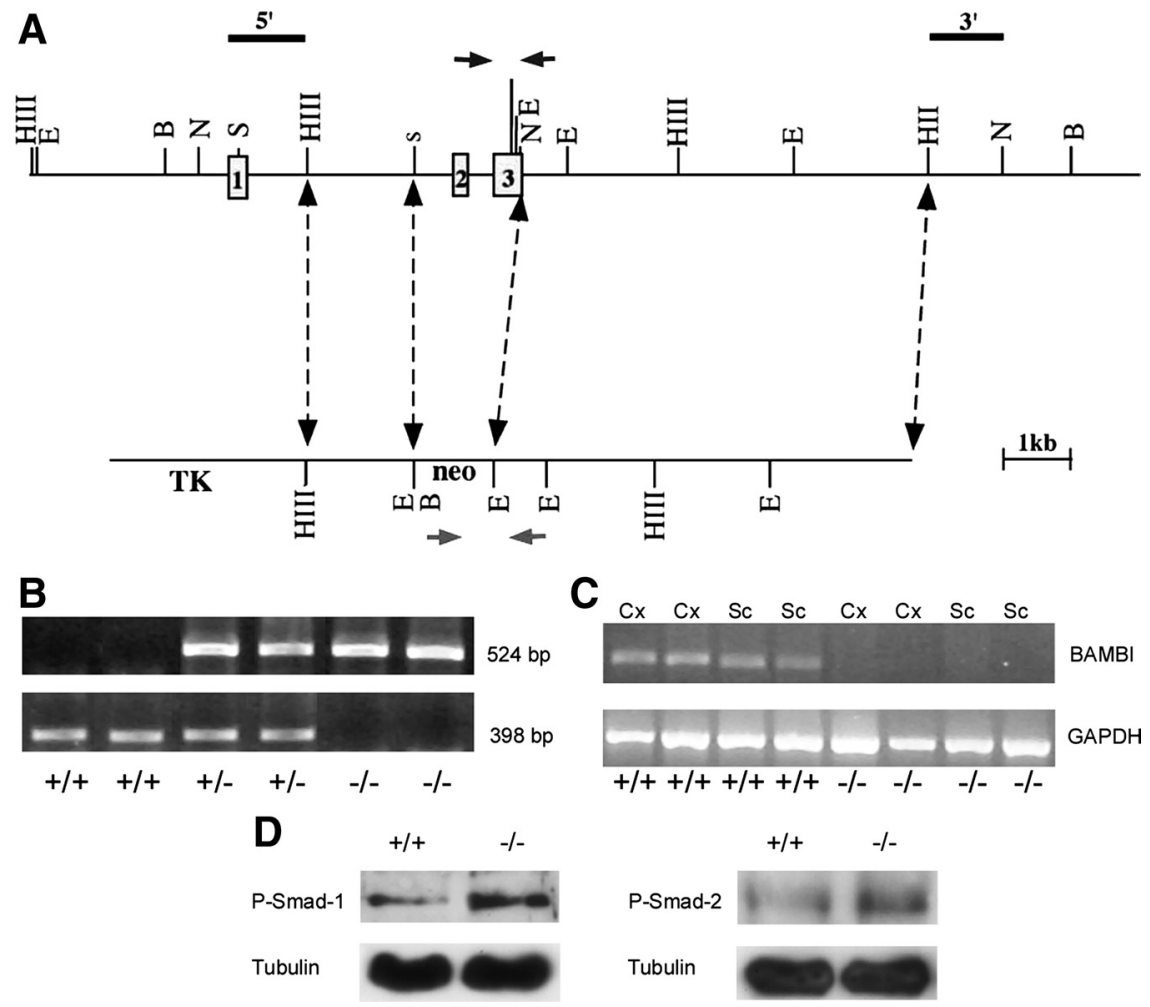

Figure 1. Targeted disruption of the BAMBI gene by homologous recombination. $A$, Gene-targeting strategy. Top, Wild-type BAMBI locus showing exons $1-3$ (filled boxes). Bottom, Targeting vector in which exons 2 and 3 were replaced with the neomycin (neo) resistance marker. Arrows indicate the position of the primers used for genotyping. $B, P C R$ analysis of genomic DNA from $\mathrm{BAMBI}^{+/+}, \mathrm{BAMBI}^{+/-}$, and $\mathrm{BAMBI}^{-/-}$mice. C, RT-PCR analysis of $B A M B \mathrm{ImRNA}$ expression in the brain cortices $(\mathrm{C})$ and spinal cords (Sc) of $B A M B I^{+/+}$and $B A M B I^{-/-}$mice. GAPDH, Glyceraldehyde-3-phosphate dehydrogenase. D, Representative Western blot of phosphorylated Smad1 and Smad2 proteins in the spinal cord of $\mathrm{BAMII}^{+/+}$and $\mathrm{BAMBI}^{-/-}$mice.

The biological processes regulated by the TGF- $\beta$ family of cytokines in the rodent developing nervous system have been extensively studied (Böttner et al., 2000). In the adult CNS, more or less strong signals for several members and receptors of the TGF- $\beta$ family are still detectable (Funaba et al., 1997; Mehler et al., 1997; Böttner et al., 2000; Unsicker and Strelau, 2000; Chen et al., 2003; Fan et al., 2003; Mikawa et al., 2006), supporting a role as modulators of neural functions in the adulthood. Among the functions exerted by TGF- $\beta$ s in the mature CNS, neuroprotection, neurogenesis, and repair process orchestration are best studied (Brionne et al., 2003; Israelsson et al., 2006; Vivien and Ali, 2006; Ageta et al., 2008). Recently, it has been reported that TGF- $\beta 1$ alleviates neuropathic pain in rats, and the suggested mechanism involves an inhibitory effect on the spinal cord inflammatory response to nerve injury and a neuroprotective effect on damaged neurons (Echeverry et al., 2009).

In this work, we generated mutant mice, lacking the TGF- $\beta$ signaling inhibitor BAMBI, to investigate whether the TGF- $\beta$ family is involved in nociceptive processing under physiological and pathological conditions. Herein, we show that $B A M B I$ is expressed in mice nociception-relevant areas and that targeted deletion of $B A M B I$ results in attenuation of both acute pain behaviors and neuropathic pain development after nerve injury. The mechanism involves the transcriptional regulation by members of the TGF- $\beta$ family of genes encoding endogenous opioid peptides.

\section{Materials and Methods}

Animals

The experiments were performed in male mice, housed in a room kept at $22^{\circ} \mathrm{C}$ with and exposed for their whole lifespan to an inverted $12 \mathrm{~h} \mathrm{light/}$ dark cycle (dark from 8:00 A.M. to 8:00 P.M.). Food and water were provided ad libitum. This study was approved by the Cantabria University Institutional Laboratory Animal Care and Use Committee, and the experiments were performed in accordance with the Declaration of Helsinki and the European Communities Council Directive (86/609/EEC) and the guidelines of the Committee for Research and Ethical Issues of International Association for the Study of Pain (Zimmermann, 1983). Every effort was made to minimize the number of animals used and their suffering.

\section{Generation of $\mathrm{BAMBI}^{-/-}$mice}

Homologous recombination in embryonic stem cells was used to create a $129 \mathrm{SvJ} \times$ C57BL/ 6 mouse line, in which exons 2 and 3 of the BAMBI gene were deleted (Fig. 1A). The remaining exon 1 contains the $5^{\prime}$ untranslated region and the first 14 amino acids, which are part of the signaling sequence characteristic of membrane-targeted or -secreted proteins. $\mathrm{Mu}-$ tant mice were backcrossed with C57BL/6 up to the F6 generation. Interbreeding of $B A M B I^{+/-}$mice resulted in homozygous mutant mice. The experiments were performed in adult (14-16 weeks) $B A M B I^{+/+}, B A M B I^{+/-}$, and $B A M B I^{-1-}$ mice. Genotyping was performed on genomic DNA extracted from tissue punched from the ear by PCR, following standard protocols with TaqDNA Polymerase (Invitrogen) (Fig. $1 B$ ). The primers were designed to amplify a $398 \mathrm{bp}$ fragment containing parts of the deleted region (forward, TGTGATAGCGGTTCCCATTGC; reverse, CCAGATAAAAGTGCTCCTGTCAGC) for the wild-type allele and a $524 \mathrm{bp}$ fragment containing part of the neomycin cassette (forward, $5^{\prime}$-TTCGCCAATGACAAGACGCTGG-3'; reverse, $5^{\prime}$-GGACACAAAGAACCCTGGGAAAG-3') for the targeted allele. The existence of $B A M B I$ transcripts in the CNS of wild-type mice as well as its absence in $B A M B I^{-1-}$ mice was confirmed by reverse transcription (RT)-PCR analyses (Fig. $1 C$ ). An increase in TGF- $\beta$ familymediated signaling in mutant mice, compared with their wild-type littermates, was reflected by the increased expression of phosphorylated Smad-1 and Smad-2 proteins observed in the brain cortex and spinal cord by Western blot analyses (Fig. 1D).

\section{General behavior studies}

Behavioral studies were performed in 14-week-old mice $(n=8-12$ per group) by observers blinded to the genotypes of the animals. Mice sensorimotor functions were evaluated in a battery of tests assessing motor activity, sensorimotor reflexes, equilibrium, and coordination as described previously (Martínez-Cué et al., 2005). Mice performed the behavioral tests during their activity (dark) phase, under dim red light.

\section{Acute pain behavior studies}

The warm-water tail-flick test was performed by immersing the tip of the tail $(2-3 \mathrm{~cm})$ into the water. The time it took to remove the tail from the water heated to 45,47 , and $49^{\circ} \mathrm{C}$ was measured (cutoff time, $60 \mathrm{~s}$ ). In the hotplate test, mice were placed on a 50 or $52^{\circ} \mathrm{C}$ hotplate, and the delay to hindpaw licking and jump were recorded (cutoff time, $120 \mathrm{~s}$ ). In the Formalin test, mice received a $20 \mu \mathrm{l}$ intraplantar injection of a $2 \%$ Formalin solution in the left hindpaw, and the time spent licking the paw was recorded within the first $5 \mathrm{~min}$ (first phase) and from 20 to $30 \mathrm{~min}$ after injection (second phase). The mechanical withdrawal threshold test was performed by applying an ascending series of calibrated von Frey hairs to the plantar surface of each hindpaw until a withdrawal response was observed. The results are expressed as percentage of paw withdrawals in response to stimuli of increasing strength $(0.1-10 \mathrm{~g})$ applied five times 
each, and $50 \%$ of responses is considered the mechanical withdrawal threshold (in grams). All tests were performed with 8-12 animals per group.

\section{Chronic neuropathic pain behavior studies}

Sciatic nerve crush injury. To induce the development of neuropathic pain, mice were subjected to sciatic nerve crush injury (Bester et al., 2000) under inhalation anesthesia with isoflurane (induction, 3\%; surgery, $1.5 \%)$. The left common sciatic nerve was exposed via blunt dissection through the biceps femoris muscle. The nerve was isolated from surrounding connective tissue at the midthigh level and crushed for $7 \mathrm{~s}$ using smooth forceps. The muscle and skin layers were closed under aseptic conditions. Control cohorts (sham-operated mice) underwent the same surgical procedure, but the nerve was exposed and left intact. The time course of neuropathic pain development, manifested as mechanical hypersensitivity and tactile allodynia (painful responses to normally innocuous stimuli), was assessed by the application of von Frey filaments to the plantar surface of the hindpaw before surgery and at days 3, 7, 10, 14, and 18 after crush injury of the sciatic nerve. A series of mice, subjected to sciatic injury for $14 \mathrm{~d}$, were treated with either the nonselective opioid antagonist naloxone (NLX) $(1 \mathrm{mg} / \mathrm{kg}$; Sigma) or the selective antagonists of $\mu$-opioid [ $\beta$-funaltrexamine ( $\beta$-FNA); $15 \mathrm{mg} / \mathrm{kg}$; Tocris Bioscience], $\delta$-opioid (naltrindole; $10 \mathrm{mg} / \mathrm{kg}$; Tocris Bioscience), and $\kappa$-opioid [norbinaltorphimine (nor-BNI); $10 \mathrm{mg} / \mathrm{kg}$; Tocris Bioscience] receptors before measuring mechanical responsiveness to von Frey filaments.

Spared nerve injury model of neuropathic pain. An additional set of experiments was performed using the "spared nerve injury" (SNI) model (Decosterd and Woolf, 2000) of neuropathic pain. Mononeuropathy was induced according to the method originally described in the rat (Decosterd and Woolf, 2000) and reproduced in the mouse (Bourquin et al., 2006). Mice were anesthetized with isoflurane (induction, 3\%; surgery, $1.5 \%$ ). The left common sciatic nerve was blunt dissected through the biceps and femoris muscle, freed of connective, and the three peripheral branches (sural, common peroneal, and tibial nerves) of the sciatic nerve were exposed. The tibial and common peroneal nerves were ligated and transacted together. The sural nerve was carefully preserved by avoiding any nerve stretch or nerve contact with surgical tools. The muscle and skin layers were closed under aseptic conditions. Control cohorts (sham-operated mice) underwent the same surgical procedure, but the sciatic nerve was exposed and left intact. The time course of mechanical allodynia-like behavior was measured in the non-injured sural nerve skin territory from days 1 to 15 after surgery by the application of von Frey filaments.

\section{In situ hybridization}

In situ hybridization studies were performed, as described previously (Zuzarte-Luís et al., 2004), in paraformaldehyde-fixed CNS coronal sections $(100 \mu \mathrm{m})$ using digoxigenin-labeled antisense RNA probes of the BAMBI, ALK-3/BMPRIa, ALK-4/ActRIb, and ALK-6/BMPRIb genes. The specificity of labeling was established using sense riboprobes. Reactions were developed with BM Purple AP substrate (Roche).

\section{Immunohistochemistry and immunofluorescent staining}

Immunohistochemical staining was performed in formaldehyde-fixed, paraffin-included spinal cord sections of $6 \mu \mathrm{m}$ thickness. Antigen retrieval was performed by heating the slides immersed in sodium citrate buffer (10 mu sodium citrate and $0.05 \%$ Tween 20, pH 6.0) for $5 \mathrm{~min}$ in a pressure boiler. Sections were incubated overnight at $4^{\circ} \mathrm{C}$ with a goat anti-BAMBI polyclonal primary antibody (1:25; R \& D Systems), followed by a $60 \mathrm{~min}$ incubation at room temperature with a peroxidaseconjugated secondary antibody. Slides were developed using diaminobenzidine (Sigma) as chromogen. Omission of primary or secondary antibodies completely abolished specific staining.

For immunofluorescent staining, the animals were perfused, under deep pentobarbital anesthesia, with $3.7 \%$ paraformaldehyde in PBS (freshly prepared). Dorsal horn spinal cord and dorsal root ganglion fragments were removed from $300 \mu \mathrm{m}$ sections and washed in PBS. Each tissue fragment was transferred to a drop of PBS on a siliconized slide, and squash preparations of dissociated neurons and glia were performed following the procedure reported previously (Pena et al., 2001). Then, the samples were sequentially treated with $0.5 \%$ Triton X-100 in PBS for 30 min, PBS for 10 min two times, and $0.01 \%$ Tween 20 in PBS for 10 min. The samples were incubated overnight at $4^{\circ} \mathrm{C}$ with the following primary antibodies: mouse monoclonal antibody anti-BAMBI (1:50; Abnova) and rabbit anti-glial fibrillary acid protein (GFAP) polyclonal antibody (1:200; Dako), followed by $60 \mathrm{~min}$ incubation at room temperature in the specific secondary antibodies conjugated with FITC or Texas Red (Jackson ImmunoResearch). 4',6-Diamino-2-phenylindole dihydrochloride (DAPI) was also used as a nuclear counterstain (1:1000; Sigma). Omission of primary or secondary antibodies completely abolished specific staining.

\section{RNA isolation, cDNA synthesis, and real-time PCR}

Total RNA from tissue was obtained by TRIzol extraction (Invitrogen). One microgram of the isolated RNA was reverse transcribed into cDNA with an RT-PCR kit (Fermentas), according to the instructions of the manufacturer. Quantitative, real-time PCR was conducted on an MX3000P Stratagene thermocycler using specific TaqMan expression assays (Applied Biosystems) and Universal PCR Master Mix (Takara). Results were normalized to the housekeeping genes glyceraldehyde-3-phosphate dehydrogenase or ribosomal $18 \mathrm{~S}$ subunit expression and measured in parallel in each sample. Results are expressed as $\Delta \Delta$ Ct. Duplicate transcript levels were determined in three independent experiments.

\section{Western blot}

Whole-cell lysates were prepared from the cerebral cortices, hippocampus, and spinal cords. Equal amounts of whole-cell protein were resolved on $12.5 \%$ SDS-PAGE and transferred to a polyvinylidene difluoride membrane. The following primary antibodies were used: anti-phospho-Smad-2 (1:1000; catalog \#3101; Cell Signaling Technology); anti-phospho-Smad-1 (1:1000; a gift from Dr. C. H. Heldin, Ludwig Institute for Cancer Research, Uppsala University, Uppsala, Sweden), and anti-proopiomelanocortin (POMC) (1:1000; ab32893; Abcam). Immunoreactivity was detected with GE Healthcare ECL Advanced detection reagents and visualized by GE Healthcare Hyperfilm-ECL. Films were scanned, and optical densities were determined by using the Scion Image software (Scion Corporation).

\section{Radioimmunoassay}

After decapitation, the spinal cords of the mice were extracted by hydroextrusion and immediately frozen in liquid nitrogen. Peptides were extracted as described. Radioimmunoassay (RIA) of Leu-enkephalin and Dynorphin A was performed using commercial kits (Phoenix Pharmaceuticals), following the recommendations of the manufacturer. Each sample was assayed in triplicate.

\section{Spinal cord explants stimulation}

Mice were anesthetized and decapitated. The spinal cord was extracted by hydro-extrusion (De Sousa and Horrocks, 1979) and dissected through the middle line to obtain two hemi-spinal cords. Each hemi-spinal cord was placed onto a Millicell-CM culture plate (Millipore Corporation) and inserted into a six-well plate. Spinal cords were incubated for $1 \mathrm{~h}$ in $1.5 \mathrm{ml}$ of DMEM (Sigma) with or without recombinant BMP-7 (20 ng/ $\mathrm{ml}$; R \& D Systems) or activin ( $20 \mathrm{ng} / \mathrm{ml}$; R \& D Systems), in a humidified atmosphere of $5 \% \mathrm{CO}_{2}$, at $37^{\circ} \mathrm{C}$. Each hemi-spinal cord served as the control for its complementary half. RNA isolation, retrotranscription to cDNA, and real-time PCR were performed as described previously.

\section{Data analysis and statistics}

Behavioral experiments were conducted blindly as to the genotype of the mice. All results are presented as mean \pm SEM. Statistical differences between genotypes were analyzed with one-way, two-way, or repeatedmeasures ANOVA, followed by Bonferroni's test. Individual time points were analyzed with unpaired $t$ test. For all analyses, $p<0.05$ was considered significant.

\section{Results}

\section{Regional distribution of BAMBI in the nervous system}

Representative in situ hybridization images at the mesencephalic and spinal cord levels are presented in Figure 2, $A$ and $B$. Strong 

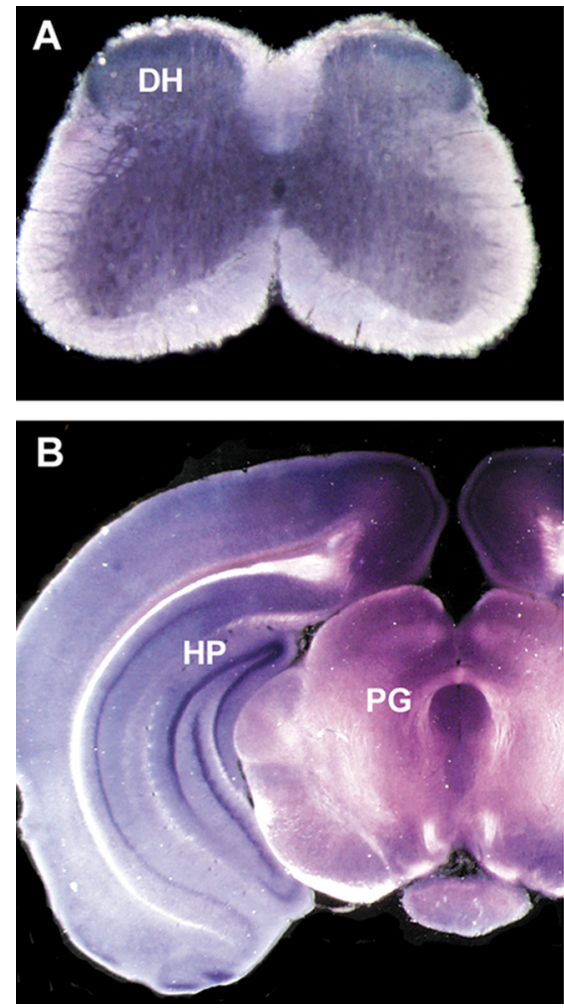
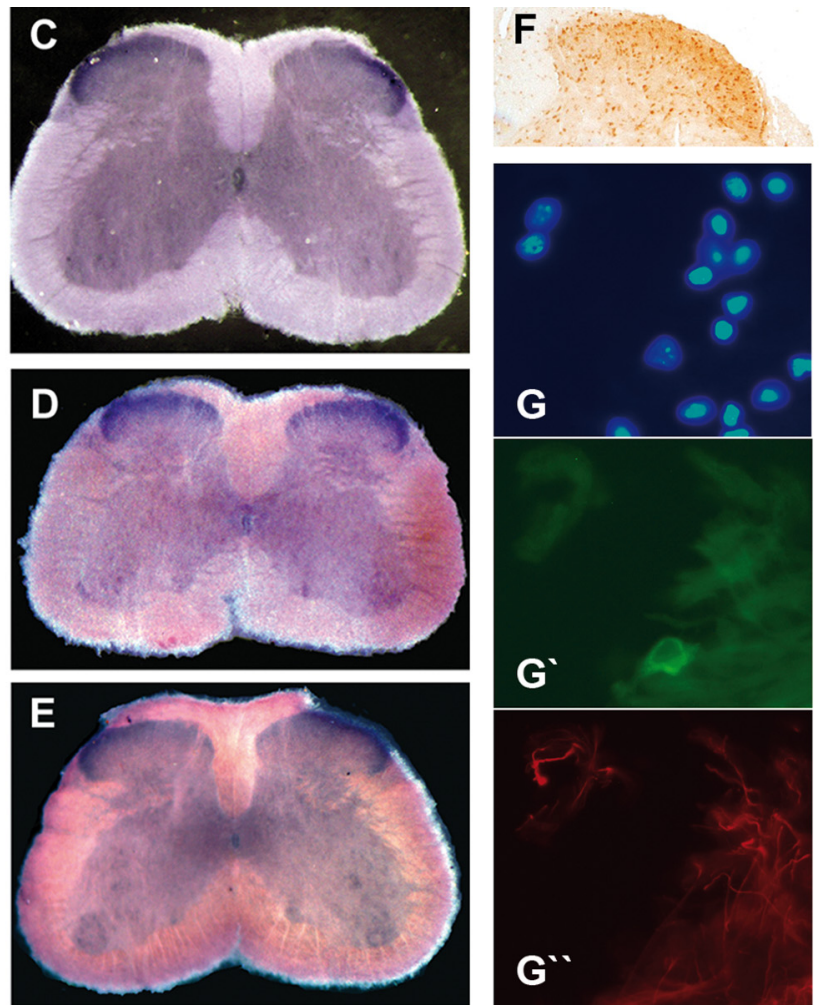

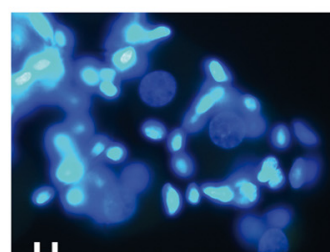

H

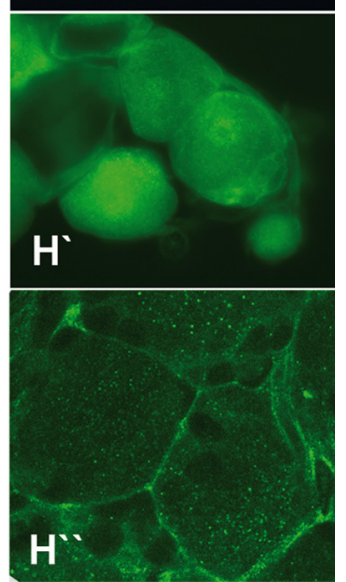

Figure 2. In situ hybridization showing the distribution of BAMBI mRNA in the spinal cord $(\boldsymbol{A})$ and brain $(\boldsymbol{B})$ and type I receptors ALK-4 (C), ALK-3 (D), and ALK-6(E) mRNA in the spinal cord. One-hundredmicrometer coronal sections were hybridized with digoxigenin-labeled riboprobes. Immunohistochemical staining evidenced the presence of BAMBl immunoreactivity in the superficial layers of the spinal cord dorsal horn $(\boldsymbol{F})$. Representative immunofluorescence images from squash preparations of dissociated neurons and glia from dorsal horn $\left(\boldsymbol{G}-\boldsymbol{G}^{\prime \prime}\right)$ and dorsal root ganglion $\left(\boldsymbol{H}-\boldsymbol{H}^{\prime \prime}\right)$. The nuclei were counterstained with $\operatorname{DAPI}(\boldsymbol{G}, \boldsymbol{H})$. BAMBl immunoreactivity (green) was detected in some neurons within dorsal horn $\left(\boldsymbol{G}^{\prime}\right)$ with negligible presence in astrocytes stained (red) with GFAP ( $\left.\boldsymbol{G}^{\prime \prime}\right)$. In dorsal root ganglion, BAMBI signal was present in neurons $\left(\boldsymbol{H}^{\prime}\right)$ but absent in their surrounding satellite glial cells. Confocal high-magnification immunofluorescence images indicate a peripheral expression pattern of BAMBl immunoreactivity $\left(\boldsymbol{H}^{\prime \prime}\right)$, consistent with its transmembrane localization. HP, Hippocampus; $\mathrm{PG}$, mesencephalic periaqueductal gray; DH, dorsal horn of the spinal cord.

labeling levels of $B A M B I$ were detected in the cingulate, retrosplenial and piriform cortex, the CA1, CA2, and CA3 hippocampal fields, the dentate gyrus, the posterior thalamic nuclei, the lateral hypothalamic area, the substantia nigra, the ventral tegmental area, the periaqueductal gray matter, and the dorsal horn of the spinal cord. The expression of $B A M B I$ in dorsal horn overlaps with several type I receptors for TGF- $\beta$ family members, such as ALK-3, ALK-4, and ALK-6 (Fig. 2C-E). Control experiments, using sense riboprobes, showed no signal (data not shown).

As observed for $B A M B I$ transcripts, immunohistochemical staining evidenced the presence of BAMBI immunoreactivity in the superficial layers of the spinal cord dorsal horn (Fig. $2 F$ ). Immunofluorescence performed in squash preparations of dissociated neurons and glia evidenced that BAMBI immunoreactivity is located preferentially in neurons (Fig. $2 G^{\prime}$ ). High levels of BAMBI immunoreactivity were also detected in virtually all dorsal root ganglion neurons (Fig. $2 H^{\prime}, H^{\prime \prime}$ ) but were absent in their surrounding satellite glial cells. High-magnification confocal immunofluorescence images (Fig. $2 H^{\prime \prime}$ ) disclosed a peripheral expression pattern of BAMBI immunoreactivity, consistent with its transmembrane localization.

\section{Lack of BAMBI has no effect on general behavior}

Mutant mice were fertile, appeared healthy, showed no apparent phenotypic defects, and displayed longevity that was indistinguishable from wild-type littermates. Their sensorimotor abilities, locomotor activity, and coordination, measured in the open field and the rotarod tests, were similar to those of wild-type (data not shown).
Lack of BAMBI reduces basal nocifensive responses in thermal, mechanical, and chemical/inflammatory tests of acute pain

We examined the behavioral responses of $B A M B I^{-/-}$mice to noxious thermal ( $n=12$ per group), chemical/inflammatory ( $n=8$ per group), and mechanical $(n=12$ per group) stimuli tests (Vierck, 2006). Two models of thermal nociception were used: the warm-water tail-immersion test that examines spinalmediated responses, and the hotplate test that examines both spinal and supraspinal-mediated responses. In the tail-immersion test, $B A M B I^{-1-}$ mice experienced a significantly greater delay in tail withdrawal than the wild-type mice at 45,47 , and $49^{\circ} \mathrm{C}$ (Fig. $3 A$ ). Furthermore, there was a gene-dosage dependence of the response, because the reaction time of the $B A M B I^{+/-}$mice occurred between wild-type and knock-out mice (Fig. $3 B$ ). The delays in licking behavior and jumping from a hotplate set at $50^{\circ} \mathrm{C}$ (Fig. $3 C$ ) and $52^{\circ} \mathrm{C}$ were also significantly longer in $B A M B I^{-/-}$ mice than in their wild-type littermates.

The effect of BAMBI deletion on chemical pain behavior was assessed in the Formalin test. Injection of Formalin into the hindpaw induces a biphasic pain response; the first phase is thought to result from direct activation of TRPA1 cation channel in primary afferent sensory neurons, whereas the second phase has been proposed to reflect the combined effects of afferent input and activity-dependent sensitization of CNS neurons within the dorsal horn (Coderre et al., 1990; Tjølsen et al., 1992; McNamara et al., 2007). Intradermal injection of Formalin into the hindpaw produced the typical biphasic paw-licking behavior in wild-type and $B A M B I^{-/-}$mice; however $B A M B I^{-/-}$mice showed a signif- 


\section{$B A M B I+/+$}

A

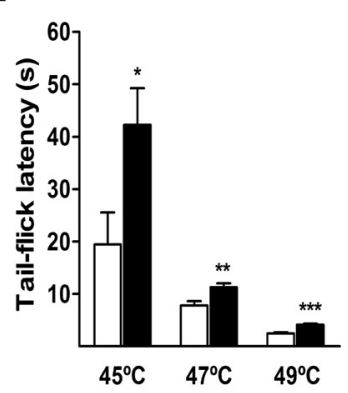

C

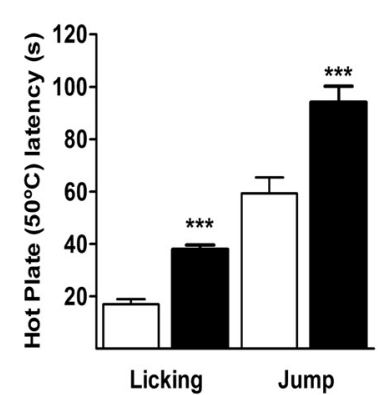

E

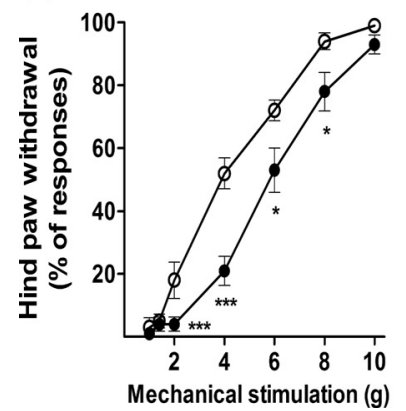

\section{$B A M B I+/ \square B A M B I-/-$}

B
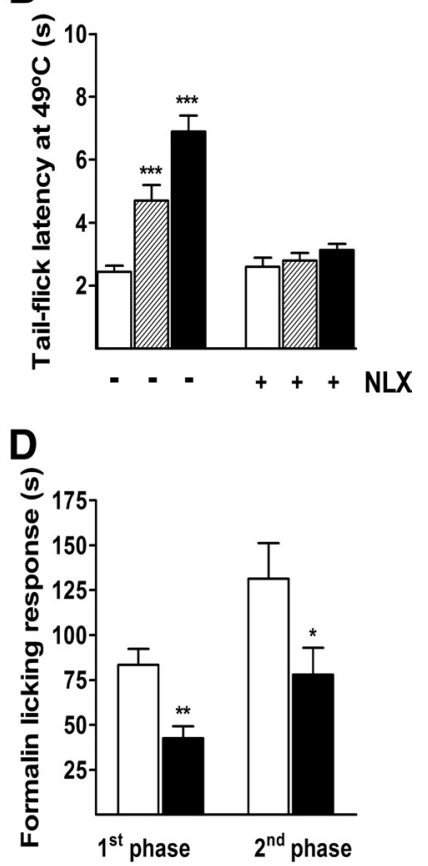

$\mathbf{F}$

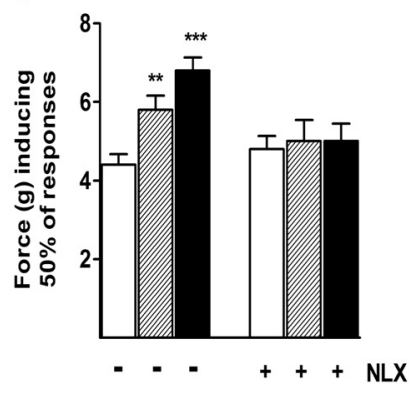

Figure 3. Responses to acute painful stimuli. $\boldsymbol{A}$, Warm-water tail-flick assay assessed at 45 , 47 , and $49^{\circ} \mathrm{C} . \boldsymbol{B}$, Effect of the pretreatment with NLX (1 mg/kg, i.p.) on tail-flick latencies. C, Hotplate licking and jump latencies at $50^{\circ} \mathrm{C}$. D, Cumulative time spent licking the hindpaw after subcutaneous injection of Formalin ( $20 \mu \mathrm{l}$ of $2 \%$ Formalin) into the plantar surface from 0-5 min (first phase) and 20-30 min after injection (second phase). $\boldsymbol{E}$, Mechanical stimulation test (von Frey monofilaments). Values are the percentage of hindpaw withdrawals in response to stimuli of increasing strength. $\boldsymbol{F}$, Effect of NLX (1 mg/kg, i.p.) on the mechanical sensitivity threshold. Note that, after naloxone treatment, $B A M B I^{-1-}$ mice showed a normalization in the withdrawal response to both thermal and mechanical stimuli, whereas no changes were evident in wild-type mice. Data are means \pm SEM. ${ }^{*} p<0.05$, ${ }^{* *} p<0.01$, and ${ }^{* * *} p<0.001$ versus $B A M B I^{+/+}$mice (two-tailed Student's $t$ test).

icantly reduced pain behavior during both the early (acute) and the second (tonic) phases of the test (Fig. 3D).

In the von Frey test of mechanical sensitivity, which depends on the firing of mechanosensitive $\mathrm{A} \delta$-fibers and polymodal C-fibers, the hindpaw-withdrawal response to stimulation at graded intensities of force was less pronounced in $B A M B I^{-/-}$ mice than in the wild-type mice (Fig. 3E). The gene-dosage dependence of the mechanically induced paw response was also evident (Fig. 3F).

These results indicate the involvement of TGF- $\beta$ s in nociceptive processing, regardless of the modality of the noxious stimuli (thermal, mechanical, and chemical/inflammatory).
Lack of BAMBI attenuates the expression of neuropathic pain responses

We assessed the potential involvement of BAMBI in chronic pain behaviors in two models of neuropathic pain that mimics peripheral nerve injury in humans: the crush injury of sciatic nerve (Bester et al., 2000) and the spared nerve injury (Decosterd and Woolf, 2000; Bourquin et al., 2006).

In the crush injury of sciatic nerve model, we evaluated the nocifensive response to the hindpaw tactile mechanical stimulation at graded intensities of stimuli for $18 \mathrm{~d}$ after crush $(n=10$ per group). Wild-type mice displayed a progressive and significant decrease in the paw-withdrawal threshold, starting at day 7 and reaching the maximal allodynic response $14 \mathrm{~d}$ after crush. ANOVA indicated that $B A M B I^{-/-}$mice were significantly less sensitive to mechanical stimuli compared with the wild-type group throughout the follow-up period (ANOVA; genotype: $F_{(1,90)}=39.9, p<0.001$; time: $F_{(5,90)}=48.9, p<0.001$; genotype $\times$ time: $F_{(5,90)}=6.8, p<0.001$ ). In Figure 4 (top), we show representative graphs showing the reduced nocifensive responses of $B A M B I^{--}$mice to hindpaw mechanical stimulation, at graded intensities of force on day 14 after injury compared with their wild-type littermates (genotype: $F_{(1,69)}=80.7, p<0.001$; nerve injury: $F_{(1,69)}=97.1, p<0.001$; genotype $\times$ nerve injury: $\left.F_{(1,69)}=25.0, p<0.001\right)$.

In the spared nerve injury model of neuropathic pain $(n=7-9$ animals per group) $B A M B I^{-/-}$mice also exhibited a lower degree of mechanical allodynia than their wild-type littermates as indicated two-way ANOVA (genotype: $F_{(1,104)}=90.8, p<0.001$; nerve injury: $F_{(1,104)}=199.3, p<0.001$; genotype $\times$ nerve injury: $\left.F_{(1,104)}=13.1, p<0.001\right)$ (Fig. 5).

The opioid antagonist naloxone reverses thermal and mechanical hyposensitivity in $B A M B I^{-/-}$mice

The presence of BAMBI transcripts in the dorsal horn of the spinal cord and the periaqueductal gray matter, paradigmatic areas in which the endogenous opioidergic system plays a key role in processing nociceptive information (Fields, 2000), directed us to examine whether the reduced sensitivity to pain in the mutant mice was linked to an opioid-mediated mechanism. For this purpose, a series of mice ( $n=10$ per group) were pretreated with the nonselective opioid receptor antagonist naloxone $(1 \mathrm{mg} / \mathrm{kg}$, i.p.) 30 min before performing the warm-water tail-immersion and von Frey tests. After naloxone treatment, $B A M B I^{-/-}$mice showed a normalization in the withdrawal response to both thermal and mechanical stimuli, whereas no changes were evident in wild-type mice; thus, both groups of animals became equally responsive to pain (Fig. $3 B, F$ ). These results indicate that the endogenous opioid system is involved in the reduced nocifensive responses to painful stimuli displayed by $B A M B I^{-/-}$mice under basal conditions.

The anti-allodynic phenotype of $B A M B I^{-/-}$mice involves $\delta$-opioid receptor activity

Fourteen days after sciatic nerve injury (Fig. 4, bottom), when maximal differences in neuropathic pain-related behaviors between genotypes were evident, naloxone administration $(n=10$ per group) triggered mechanical hypersensitivity and allodynia in $B A M B I^{-1-}$ mice but did not influence significantly the nociceptive response in the wild-type group (genotype: $F_{(1,69)}=16.6, p<$ 0.001 ; NLX treatment: $F_{(1,69)}=11.5, p<0.01$; genotype $\times$ treatment: $\left.F_{(1,69)}=4.5, p<0.05\right)$. To further define the opioid receptor subtype(s) responsible for the anti-allodynic phenotype, a series of $B A M B I^{-/-}$mice, subjected to sciatic nerve injury for $14 \mathrm{~d}$, were 


\section{Wild type mice}
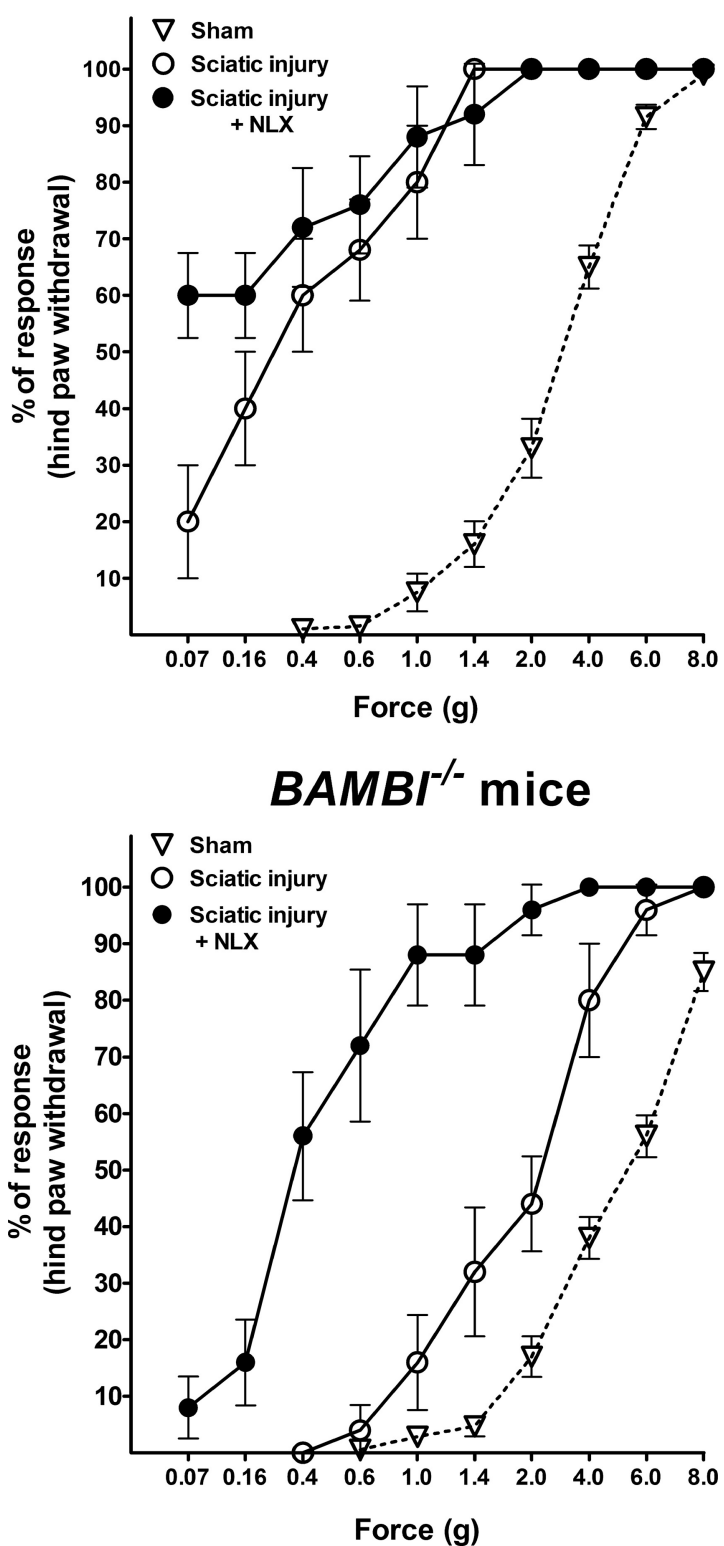

Figure 4. Development of neuropathic pain in response to crush injury of sciatic nerve. Representative graphs showing the behavioral manifestations of neuropathic pain (mechanical allodynia) evaluated with the von Frey monofilaments, on day 14 after nerve injury and the effect of naloxone pretreatment before performing the von Frey test. Values are the mean \pm SEM percentage of hindpaw withdrawals elicited by mechanical stimuli of increasing strength, in wild-type (top graph) and $\mathrm{BAMBI}^{-/-}$(bottom graph) mice subjected to sham operation (triangles) or sciatic nerve injury (circles). Two-way ANOVA indicates that $\mathrm{BAMBI}^{-1-}$ mice were significantly less sensitive to mechanical stimuli compared with their wild-type littermates. Naloxone treatment (filled circles) before performing the mechanical test, on day 14 after nerve injury triggered mechanical allodynia in $B A M B I^{-1-}$ mice, whereas no significant changes in mechanical sensitivity were evidenced in wild-type mice.

pretreated with selective antagonists of the different opioid receptor types, $60 \mathrm{~min}$ before analyzing the development of mechanical hypersensitivity. Subsequently, mice received a dose of naloxone to evaluate the degree of antagonism reached with each drug. As shown in Figure 6, the $\delta$-selective antagonist naltrindole fully reversed the anti-allodynic phenotype $\left(F_{(1,67)}=490, p<0.001\right)$, whereas the $\mu$-opioid $\left(\beta\right.$-FNA; $\left.F_{(1,67)}=48.5, p<0.001\right)$ and $\kappa$-opioid (nor-BNI; $\left.F_{(1,67)}=4.7, p<0.05\right)$ selective antagonists were barely effective.

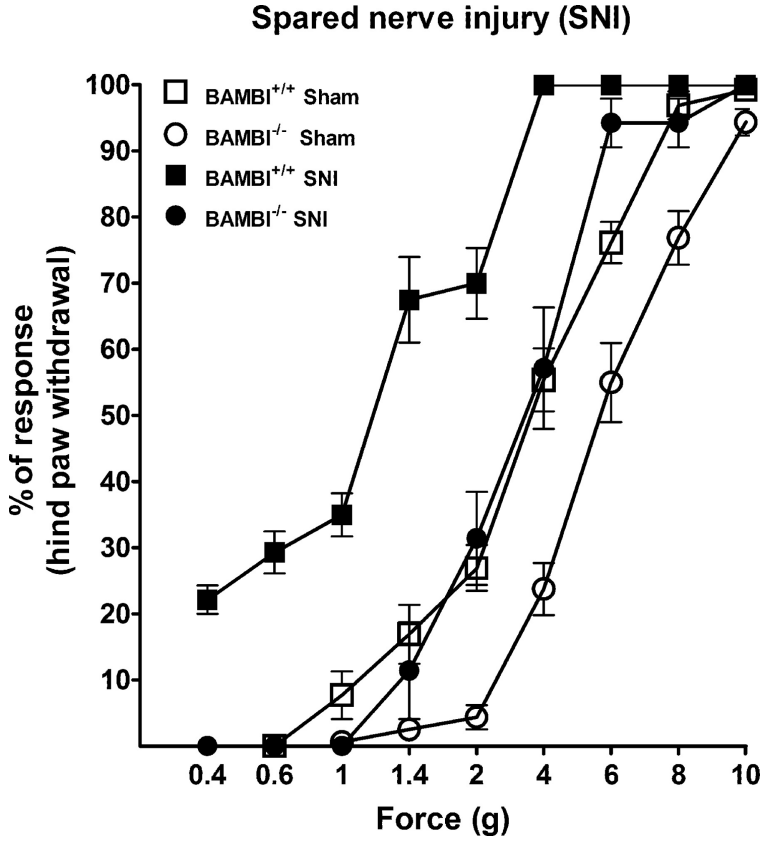

Figure 5. Development of neuropathic pain in response to spared nerve injury. Representative graphs showing the behavioral manifestations of neuropathic pain (mechanical allodynia) evaluated with the von Frey monofilaments, on day 14 after SNI surgery in $B A M B I^{-1-}$ (filled circles) and wild-type (filled squares) mice. Values are the mean \pm SEM percentage of hindpaw withdrawals elicited by mechanical stimuli of increasing strength, in wild-type (triangles) and $B A M B I^{-1-}$ mice (circles), subjected to sham operation (open symbols) or SNI surgery (filled symbols). Two-way ANOVA indicates that $\mathrm{BAMBI}^{-1-}$ mice were significantly less sensitive to mechanical stimuli compared with their wild-type littermates. Note also the difference in mechanical sensitivity between sham-operated $\mathrm{BAMI}^{+/+}$and $\mathrm{BAMBI}^{-/-}$mice.

Basal expression of POMC mRNA and protein, as well as proenkephalin mRNA and the derived opioid peptide Leu-enkephalin, is increased in $B A M B I^{-/-}$spinal cord Given the regulatory function exerted by TGF- $\beta$ s on gene transcription, we analyzed whether the spinal cord expression levels of genes encoding endogenous opioid peptides was affected by $B A M B I$ deletion. Our results indicated that the basal level of $P O M C$ mRNA, the gene codifying for $\beta$-endorphin, was $2.46 \pm$ 0.30 -fold (95\% confidence level, 1.63-3.29; $p=0.022$, two-tailed $t$ test) higher in the $B A M B I^{-/-}$mice $(n=5)$ than in the wild type $(n=5)$. We also observed a $1.64 \pm 0.11$-fold increase $(95 \%$ confidence level, 1.32-1.97; $p=0.007$, two-tailed $t$ test) in the basal level of proenkephalin (PENK) mRNA, the gene codifying for enkephalins, in $B A M B I^{-/-}$mice compared with wild-type mice. Conversely, the basal level of prodynorphin (PDYN) mRNA, the gene codifying for dynorphins, was similar in both genotypes. To assess that increased transcription is translated to the protein level, we determined by Western blot or RIA the expression levels of the different opioid peptides. Spinal expression levels of POMC protein, determined by Western blot, and Leu-enkephalin, measured by RIA, were higher in $B A M B I^{-/-}$ than in wild-type mice (POMC: $+43.8 \pm 11.9 \%, p=0.034$; PENK: $+44.2 \pm 9.0 \%, p=0.011)$. No differences between genotypes were observed in the spinal cord concentration of dynorphin, measured by RIA (data not shown).

As shown in Table 1, the spinal cord expression levels of genes encoding POMC, PENK, and PDYN were significantly and inversely related to $B A M B I$ expression, whereas directly correlated with the mRNA levels of various TGF- $\beta$ family members (TGF$\beta 1$, activin, and BMP-7) and with representative intracellular 

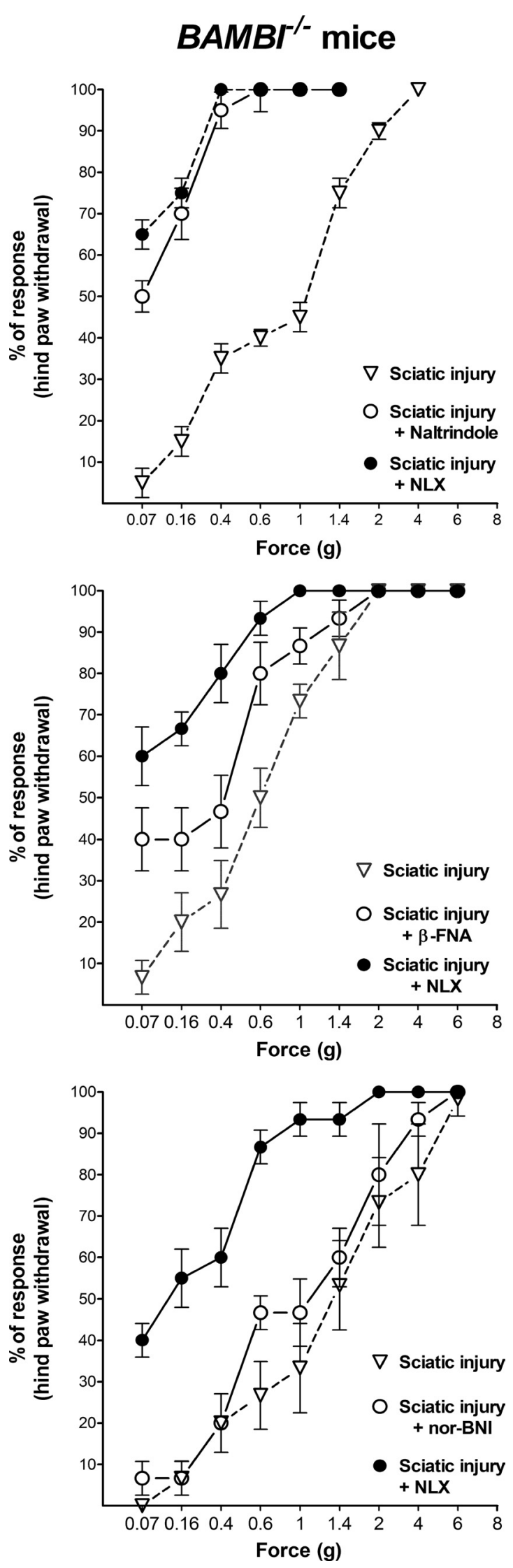

Figure 6. Effects of specific opioid antagonists on neuropathic pain behavior in $B A M B I^{-/-}$ mice. Representative graphs showing the behavioral manifestations of neuropathic pain (mechanical allodynia) evaluated with von Frey monofilaments, on day 14 after sciatic nerve crush injury (triangles), and the effect of pretreatment with selective opioid antagonists before effectors from the TGF- $\beta$ canonical (common SMAD4) and alternative (TAK1) signaling pathways (Wrana et al., 1994). These results led us to test whether exogenously administered recombinant TGF- $\beta$ s influence transcriptional regulation of POMC and PENK under basal conditions. For this purpose, explanted spinal cords from wild-type mice were cultured in the presence of recombinant activin A (20 ng/ml) or BMP-7 (20 ng/ml) for $1 \mathrm{~h}$, and POMC and PENK expression levels were assessed by quantitative RT-PCR. Because the TGF- $\beta$ members acting physiologically on the spinal cord remain to be identified, we selected activin A and BMP-7 because they signal through the two different major Smad pathways in TGF- $\beta$ superfamily signaling: activin/TGF- $\beta$ specific R-Smads (Smads 2 and 3) or BMP-specific R-Smads (Smads 1, 5, and 8). One hour incubation of spinal cord explants with activin A or BMP-7 significantly increased POMC mRNA levels [activin A: 2.7-fold vs untreated (95\% confidence level, 1.57-3.38; two-tailed $t$ test, $p=0.039$ ); BMP-7: 1.74-fold vs untreated (95\% confidence level, 1.63-1.84; two-tailed $t$ test, $p=$ $0.0001)]$. Also, PENK mRNA levels increased significantly in explants incubated with BMP-7 versus untreated (1.64-fold; 95\% confidence level: 1.32-1.97; two-tailed $t$ test; $p=0.0079)$.

\section{Discussion}

To unravel novel roles for TGF- $\beta$ s in the adult CNS, we have examined the expression pattern and the function of BAMBI, a pseudoreceptor that modulates negatively pan-TGF- $\beta$ family signaling (Onichtchouk et al., 1999). We show that BAMBI transcripts are abundant in several CNS areas critically involved in pain processing (Fields, 2000; Todd and Koerber, 2006), such as the cingulate cortex, the mesencephalic periaqueductal gray, and the superficial laminae of the spinal cord dorsal horn. The presence of BAMBI protein and its preferential location in neurons was confirmed on the former structure by immunohistochemistry. At the peripheral level, in the dorsal root ganglion, BAMBI was also detected in virtually all sensory neurons but was absent in their satellite glia. The location of BAMBI expression is indicative of a role for TGF- $\beta$ family members in nociceptive regulation, both central and peripherally. This suggestion is further supported by a recent report showing the antiallodynic effect exerted by recombinant TGF- $\beta 1$ in a rat model of neuropathic pain (Echeverry et al., 2009). Thus, we aimed to assess possible changes in the responsiveness to painful stimuli, under conditions of enhanced TGF- $\beta$ signaling. This objective directed us to develop a mutant mouse lacking $B A M B I$. As we expected, the absence of the inhibitory influence of $B A M B I$ in knock-out mice resulted in increased levels of representative downstream effectors of the TGF- $\beta$ signaling pathway, such as the phosphorylated forms of Smad1 and Smad 2 transcription factors, in some regions of the CNS. Our first behavioral analyses was the absence in $B A M B I^{-1-}$ mice of phenotypic defects, affecting general motor and sensory functions, which could constitute confounding factors to interpret pain behaviors. Nevertheless, it should be noted that backcrossing to the sixth generation could be insufficient for complete abolition of potential "hitchhiking donor gene" confounds (Gerlai, 1996).

performing the von Frey test (open circles). The antagonistic effect achieved by subsequent naloxone administration is also shown (filled circles). Values are the mean \pm SEM percentage of hindpaw withdrawals elicited by mechanical stimuli of increasing strength. The selective antagonist of $\delta$-opioid receptors, naltrindole (top graph), fully reversed the anti-allodynic phenotype of $\mathrm{BAMBI}^{-/-}$mice, whereas the $\mu$-opioid ( $\beta$-FNA) and $\kappa$-opioid (nor-BNI) selective antagonists were much less effective. 
Table 1. Pearson's correlation coefficient values $(R)$ obtained from the linear regression analyses correlating spinal cord mRNA expression levels of TGF- $\beta 1$, BMP-2, BMP-7, activin, SMAD4, TAK1, and BAMBI with the expression of genes encoding POMC, PENK, and PDYN

\begin{tabular}{|c|c|c|c|c|c|c|c|c|c|c|c|c|c|}
\hline & TGF- $\beta 1$ & & BMP-2 & & BMP-7 & & Activin & & SMAD-4 & & TAK-1 & & BAMBI \\
\hline & WT & KO & WT & KO & WT & KO & WT & KO & WT & KO & WT & KO & WT \\
\hline POMC & $0.65^{* *}$ & $0.54^{*}$ & $0.47^{*}$ & $0.48^{*}$ & $0.57^{*}$ & $0.75^{* * *}$ & $0.54^{*}$ & $0.72^{* * *}$ & 0.30 & $0.67^{* *}$ & 0.41 & $0.72^{* * *}$ & $-0.62^{*}$ \\
\hline PENK & $0.76^{* * *}$ & $0.65^{* *}$ & $0.69^{* *}$ & $0.65^{* *}$ & $0.80^{* * *}$ & $0.71^{* * *}$ & $0.58^{*}$ & $0.63^{* *}$ & $0.64^{* *}$ & $0.80^{* * * *}$ & $0.73^{* * *}$ & $0.70^{* * *}$ & $-0.51^{*}$ \\
\hline PDYN & $0.71^{* * *}$ & $0.72^{* * *}$ & $0.75^{* * *}$ & $0.80^{* * *}$ & $0.68^{* * *}$ & $0.83^{* * *}$ & $0.61^{* *}$ & $0.68^{* *}$ & 0.39 & $0.68^{* * *}$ & $0.45^{*}$ & $0.77^{* * *}$ & $-0.54^{*}$ \\
\hline
\end{tabular}

WT, Wild type; K0, knock-out. ${ }^{*} p<0.05,{ }^{* *} p<0.01$, and ${ }^{* * *} p<0.001$.

When acute pain paradigms were tested, we observed that the absence of $B A M B I$ conditioned lower nociception-related responses, regardless of the modality of the noxious stimuli used (thermal, mechanical, and chemical/inflammatory). There was gene-dosage dependence in the nocifensive responses to thermal and mechanical stimuli, as indicated by the behavior of the heterocygotes. Thus, the nocifensive responses of $B A M B I^{-/-}$mice to noxious stimuli are consistent with the hypothesized role for TGF- $\beta$ s in controlling physiological pain perception under basal conditions. Interestingly, the opioid antagonist naloxone was able to reverse the pain-related behaviors of $B A M B I^{-/-}$mice to that of wild-type controls, indicating that the hypoalgesia exhibited by $B A M B I^{-/-}$mice under basal conditions can be attributed to an enhanced endogenous opioid tone.

In the chronic and pathological neuropathic pain model, our results indicate that, in $B A M B I^{-/-}$mice, the release of TGF- $\beta$ signaling from the inhibitory influence of BAMBI also attenuated pain hypersensitivity and allodynia induced by sciatic nerve injury over a follow-up period of $18 \mathrm{~d}$. This anti-allodynic phenotype of $B A M B I^{-1-}$ mice was also evidenced in another model of peripheral mononeuropathy, such as the spared nerve injury. These results are in agreement with the aforementioned data of Echeverry et al. (2009) showing that chronic (14 d) intrathecal infusion of recombinant TGF- $\beta 1$ prevented the development of allodynia and reversed previously established neuropathic pain in rats. The mechanism proposed by the authors involves an inhibitory effect on the spinal cord inflammatory response to nerve injury exerted by TGF- $\beta 1$. In our study, naloxone completely restored the attenuated allodynic response of $B A M B I^{-/-}$mice to that of wild type, suggesting that TGF- $\beta$ signaling is critical in controlling the expression of abnormal nociceptive responses subsequent to nerve injury, by a mechanism fully dependent on ongoing opioid receptor activation. The results obtained with selective opioid antagonists indicate that the anti-allodynic phenotype is mainly dependent on $\delta$-receptor activity.

The expression of $B A M B I$ in dorsal horn overlaps with several type I receptors for TGF- $\beta$ family members, such as ALK-3, ALK-4, and ALK-6, suggesting a functional implication of TGF- $\beta$ signaling in this region. It is well known that the dorsal horn of the spinal cord is the zone in which nociceptive primary afferent axons terminate, establishing the first synapse in the ascending pathways that convey the sensory information from peripheral receptors to the brain. It contains local neuronal circuits that are involved in modulating incoming nociceptive information before its transmission up to the brain (Todd and Koerber, 2006). The superficial laminae of the dorsal horn contains intrinsic opioid inhibitory interneurons that express enkephalin, dynorphin, and $\beta$-endorphin and also receives afferent $\beta$-endorphinergic input from the arcuate and tractus solitarius nuclei (Tsou et al., 1986; Fields, 2000). Under physiological conditions, these opioid peptides exert an inhibitory control on the incoming nociceptive through receptors located both presynaptically on nociceptor terminals and postsynaptically on intrinsic dorsal horn neurons (Yaksh et al., 1982; Kondo et al., 2005; Pasternak, 2005). Under pathological conditions, the endogenous opioidergic system has been reported to counteract the development of neuronal hyperexcitability after intense noxious drive (Guan et al., 2006) and neuropathic pain-related states after nerve injury (Hao et al., 1998; Mansikka et al., 2004).

The precursors of endogenous opioid peptides are encoded by three different genes: the PENK gene that is translated into the protein precursor of enkephalins, the PDYN gene that encodes dynorphins, and the POMC gene that gives rise to $\beta$-endorphin. Our results indicate that basal levels of POMC mRNA and POMC protein, as well as PENK gene and the opioid peptide enkephalin, are higher in the spinal cords of $B A M B I^{-/-}$mice than in those of wild type. Furthermore, the spinal cord expression levels of genes encoding precursor proteins of the opioid peptides directly correlated with members of the TGF- $\beta$ family and with their intracellular effectors Smad 4 and TAK1, whereas the relationship with $B A M B I$ was inversely proportional. These results suggest that an increased transcriptional activity of endogenous opioids is likely mediating the reduced nociceptive responses in the absence of $B A M B I$. This interpretation is also supported by the transcriptional regulatory effect exerted by recombinant BMP-7 and activin A on POMC and PENK genes, in spinal cord explants. These results are consistent with previous reports showing in vitro that members of the TGF- $\beta$ family regulate the transcription of genes coding for the endogenous opioid peptides in a variety of human and rodent cell preparations (Kamphuis et al., 1997; Kavelaars and Heijnen, 2000; Nudi et al., 2005), and in vivo (Bouret et al., 2001).

Many studies support an antinociceptive action of enkephalins and $\beta$-endorphin by negatively modulating transmission of nociceptive information at the spinal level (Yaksh et al., 1982). Furthermore, POMC and PENK gene delivery to spinal cord dorsal horn induces analgesia, which is associated with increased production of $\beta$-endorphin or enkephalin by specific subsets of spinal neurons (Hao et al., 2003; Wu et al., 2004). In addition, it has been demonstrated that mice deficient in PENK showed exaggerated behavioral responses to painful stimuli (König et al., 1996). Also, transgenic mice, with a selective deficiency of $\beta$-endorphin, lack the opioid-mediated (naloxone reversible) analgesia induced by stress (Rubinstein et al., 1996). Therefore, our data suggest that hypoalgesic-related responses in mice lacking $B A M B I$ is attributable to an increased tonic activation of opioid receptors by their endogenous ligands. Particularly, the antiallodynic phenotype is mainly dependent on $\delta$-receptor signaling, which would be consistent with the relatively high affinity of enkephalins for this receptor (Dhawan et al., 1996).

Although our study was focused on spinal mechanisms, we cannot exclude the contribution of supraspinal and peripheral mechanisms in the altered pain processing displayed by $B A M B I^{-/-}$mice. In fact, BAMBI localization in dorsal root ganglion neurons and the reduced pain behavior of $B A M B I^{-/-}$mice in the Formalin test could point to a reduction in the excitability and postinjury 
sensitization of primary sensory neurons (Tjølsen et al., 1992; McNamara et al., 2007) that play important roles in the initiation and maintenance of persistent pain.

Our present results and those of Echeverry et al. (2009) suggest that members of the TGF- $\beta$ family modulate negatively pain perception under physiological and pathological conditions. However, the opposite response has been described for activin A that is released during peripheral inflammation, acting on sensory nerve terminals to increase the expression of calcitonin-gene related peptide in dorsal root ganglion neurons and leading to enhanced pain responses (Xu et al., 2005). In addition, subcutaneous injection of activin $\mathrm{A}$ induced immediate thermal hyperalgesia in rats, through a mechanism involving acute sensitization of TRPV1, which suggests a role for activin A in injury-induced hyperalgesia (Zhu et al., 2007). The extremely variable cellular responses elicited by many TGF- $\beta$ superfamily members, depending on cell type and stimulation context, could account for these antagonic effects, and the contribution of each of these mechanisms to nociception deserves further investigation.

In conclusion, the absence of BAMBI unravels a critical role for TGF- $\beta$ signaling in nociceptive perception under physiological and neuropathic pathological conditions, through a mechanism involving transcriptional regulation of the opioid peptides. Moreover, our results suggest that specific members of the TGF- $\beta$ family, their signaling effectors, and modulator molecules could be used as therapeutic targets for the design of novel analgesic drugs that may act by increasing the activity of the endogenous opioid system.

\section{References}

Ageta H, Murayama A, Migishima R, Kida S, Tsuchida K, Yokoyama M, Inokuchi K (2008) Activin in the brain modulates anxiety-related behavior and adult neurogenesis. PLoS ONE 3:e1869.

Bester H, Beggs S, Woolf CJ (2000) Changes in tactile stimuli-induced behavior and c-Fos expression in the superficial dorsal horn and in parabrachial nuclei after sciatic nerve crush. J Comp Neurol 428:45-61.

Böttner M, Krieglstein K, Unsicker K (2000) The transforming growth factor- $\beta$ s: structure, signalling, and roles in nervous system development and functions. J Neurochem 75:2227-2240.

Bouret S, Chuoi-Mariot MT, Prevot V, Croix D, Takumi T, Jegou S, Vaudry H, Beauvillain JC, Mitchell V (2001) Evidence that TGF beta may directly modulate POMC mRNA expression in the female rat arcuate nucleus. Endocrinology 142:4055-4065.

Bourquin AF, Süveges M, Pertin M, Gilliard N, Sardy S, Davison AC, Spahn DR, Decosterd I (2006) Assessment and analysis of mechanical allodynia-like behavior induced by spared nerve injury (SNI) in the mouse. Pain 122:14.e1-14.

Brionne TC, Tesseur I, Masliah E, Wyss-Coray T (2003) Loss of TGF-beta 1 leads to increased neuronal cell death and microgliosis in mouse brain. Neuron 40:1133-1145.

Chen HL, Lein PJ, Wang JY, Gash D, Hoffer BJ, Chiang YH (2003) Expression of bone morphogenetic proteins in the brain during normal aging and in 6-hydroxydopamine-lesioned animals. Brain Res 994:81-90.

Chen J, Bush JO, Ovitt CE, Lan Y, Jiang R (2007) The TGF-beta pseudoreceptor gene Bambi is dispensable for mouse embryonic development and postnatal survival. Genesis 45:482-486.

Coderre TJ, Vaccarino AL, Melzack R (1990) Central nervous system plasticity in the tonic pain response to subcutaneous formalin injection. Brain Res 535:155-158.

Decosterd I, Woolf CJ (2000) Spared nerve injury: an animal model of persistent peripheral neuropathic pain. Pain 87:149-158.

De Sousa BN, Horrocks LA (1979) Development of rat spinal cord. I. Weight and length with a method for rapid removal. Dev Neurosci 2:115-121.

Dhawan BN, Cesselin F, Raghubir R, Reisine T, Bradley PB, Portoghese PS, Hamon M (1996) International Union of Pharmacology. XII. Classification of opioid receptors. Pharmacol Rev 48:567-592.

Echeverry S, Shi XQ, Haw A, Liu H, Zhang ZW, Zhang J (2009) Transform- ing growth factor-beta1 impairs neuropathic pain through pleiotropic effects. Mol Pain 5:16.

Fan X, Xu H, Cai W, Yang Z, Zhang J (2003) Spatial and temporal patterns of expression of Noggin and BMP4 in embryonic and postnatal rat hippocampus. Brain Res Dev Brain Res 146:51-58.

Feng XH, Derynck R (2005) Secificity and versatility in TGF- $\beta$ signaling through smads. Annu Rev Cell Dev Biol 21:659-693.

Fields HL (2000) Pain modulation: expectation, opioid analgesia and virtual pain. Prog Brain Res 122:245-253.

Fritzmann J, Morkel M, Besser D, Budczies J, Kosel F, Brembeck FH, Stein U, Fichtner I, Schlag PM, Birchmeier W (2009) A colorectal cancer expression profile that includes transforming growth factor beta inhibitor BAMBI predicts metastatic potential. Gastroenterology 137:165-175.

Funaba M, Murata T, Fujimura H, Murata E, Abe M, Torii K (1997) Immunolocalization of type I or type II activin receptors in the rat brain. J Neuroendocrinol 9:105-111.

Gerlai R (1996) Gene-targeting studies of mammalian behavior: is it the mutation or the background genotype? Trends Neurosci 19:177-181.

Grotewold L, Plum M, Dildrop R, Peters T, Rüther U (2001) Bambi is coexpressed with Bmp-4 during mouse embryogenesis. Mech Dev 100:327-330.

Guan Y, Borzan J, Meyer RA, Raja SN (2006) Windup in dorsal horn neurons is modulated by endogenous spinal $\mu$-opioid mechanisms. J Neurosci 26:4298-4307.

Hao JX, Yu W, Xu XJ (1998) Evidence that spinal endogenous opioidergic systems control the expression of chronic pain-related behaviors in spinally injured rats. Exp Brain Res 118:259-268.

Hao S, Mata M, Goins W, Glorioso JC, Fink DJ (2003) Transgene-mediated enkephalin release enhances the effect of morphine and evades tolerance to produce a sustained antiallodynic effect in neuropathic pain. Pain 102:135-142.

Harada K, Sato Y, Ikeda H, Isse K, Ozaki S, Enomae M, Ohama K, Katayanagi K, Kurumaya H, Matsui A, Nakanuma Y (2009) Epithelial-mesenchymal transition induced by biliary innate immunity contributes to the sclerosing cholangiopathy of biliary atresia. J Pathol 217:654-664.

Israelsson C, Lewén A, Kylberg A, Usoskin D, Althini S, Lindeberg J, Deng CX, Fukuda T, Wang Y, Kaartinen V, Mishina Y, Hillered L, Ebendal T (2006) Genetically modified bone morphogenetic protein signalling alters traumatic brain injury-induced gene expression responses in the adult mouse. J Neurosci Res 84:47-57.

Kamphuis S, Kavelaars A, Brooimans R, Kuis W, Zegers BJ, Heijnen CJ (1997) T helper 2 cytokines induce preproenkephalin mRNA expression and proenkephalin A in human peripheral blood mononuclear cells. J Neuroimmunol 79:91-99.

Karaulanov E, Knöchel W, Niehrs C (2004) Transcriptional regulation of BMP4 synexpression in transgenic Xenopus. EMBO J 23:844-856.

Kavelaars A, Heijnen CJ (2000) Expression of preproenkephalin mRNA and production and secretion of enkephalins by human thymocytes. Ann NY Acad Sci 917:778-783.

Khin SS, Kitazawa R, Win N, Aye TT, Mori K, Kondo T, Kitazawa S (2009) BAMBI gene is epigenetically silenced in subset of high-grade bladder cancer. Int J Cancer 125:328-338.

Kitazawa S, Kitazawa R, Obayashi C, Yamamoto T (2005) Desmoid tumor with ossification in chest wall: possible involvement of BAMBI promoter hypermethylation in metaplastic bone formation. J Bone Miner Res 20:1472-1477.

Kondo I, Marvizon JC, Song B, Salgado F, Codeluppi S, Hua XY, Yaksh TL (2005) Inhibition by spinal mu- and delta-opioid agonists of afferentevoked substance P release. J Neurosci 25:3651-3660.

König M, Zimmer AM, Steiner H, Holmes PV, Crawley JN, Brownstein MJ, Zimmer A (1996) Pain responses, anxiety and aggression in mice deficient in pre-proenkephalin. Nature 383:535-538.

Lin Z, Gao C, Ning Y, He X, Wu W, Chen YG (2008) The pseudoreceptor BMP and activin membrane-bound inhibitor positively modulates Wnt/ beta-catenin signaling. J Biol Chem 283:33053-33058.

Mansikka H, Zhao C, Sheth RN, Sora I, Uhl G, Raja SN (2004) Nerve injury induces a tonic bilateral mu-opioid receptor-mediated inhibitory effect on mechanical allodynia in mice. Anesthesiology 100:912-921.

Martínez-Cué C, Rueda N, García E, Davisson MT, Schmidt C, Flórez J (2005) Behavioral, cognitive and biochemical responses to different environmental conditions in male Ts65Dn mice, a model of Down syndrome. Behav Brain Res 163:174-185. 
Massagué J, Seoane J, Wotton D (2005) Smad transcription factors. Genes Dev 19:2783-2810.

McNamara CR, Mandel-Brehm J, Bautista DM, Siemens J, Deranian KL, Zhao M, Hayward NJ, Chong JA, Julius D, Moran MM, Fanger CM (2007) TRPA1 mediates formalin-induced pain. Proc Natl Acad Sci U S A 104:13525-13530.

Mehler MF, Mabie PC, Zhang D, Kessler JA (1997) Bone morphogenetic proteins in the nervous system. Trends Neurosci 20:309-317.

Mikawa S, Wang C, Sato K (2006) Bone morphogenetic protein-4 expression in the adult rat brain. J Comp Neurol 499:613-625.

Nudi M, Ouimette JF, Drouin J (2005) Bone morphogenic protein (Smad)mediated repression of proopiomelanocortin transcription by interference with Pitx/Tpit activity. Mol Endocrinol 19:1329-1342.

Onichtchouk D, Chen YG, Dosch R, Gawantka V, Delius H, Massagué J, Niehrs C (1999) Silencing of TGF-beta signalling by the pseudoreceptor BAMBI. Nature 401:480-485.

Pasternak GW (2005) Molecular biology of opioid analgesia. J Pain Symptom Manage 29:S2-S9.

Pena E, Berciano MT, Fernandez R, Ojeda JL, Lafarga M (2001) Neuronal body size correlates with the number of nucleoli and Cajal bodies, and with the organization of splicing machinery in rat trigeminal ganglion neurons. J Comp Neurol 430:250-263.

Rubinstein M, Mogil JS, Japón M, Chan EC, Allen RG, Low MJ (1996) Absence of opioid stress-induced analgesia in mice lacking $\beta$-endorphin by site-directed mutagenesis. Proc Natl Acad Sci U S A 93:3995-4000.

Seki E, De Minicis S, Osterreicher CH, Kluwe J, Osawa Y, Brenner DA, Schwabe RF (2007) TLR4 enhances TGF-beta signaling and hepatic fibrosis. Nat Med 13:1324-1332.

Tjølsen A, Berge OG, Hunskaar S, Rosland JH, Hole K (1992) The formalin test: an evaluation of the method. Pain 51:5-17.

Todd AJ, Koerber R (2006) Neuroanatomical substrates of spinal nociception. In: Wall and Melzack's textbook of pain, Ed 5 (McMahon SB, Koltzenburg M, eds), pp 73-90. London: Elsevier.

Togo N, Ohwada S, Sakurai S, Toya H, Sakamoto I, Yamada T, Nakano T, Muroya K, Takeyoshi I, Nakajima T, Sekiya T, Yamazumi Y, Nakamura T, Akiyama T (2008) Prognostic significance of BMP and activin membranebound inhibitor in colorectal cancer. World J Gastroenterol 14:4880-4888.

Tsang M, Kim R, de Caestecker MP, Kudoh T, Roberts AB, Dawid IB (2000) Zebrafish nma is involved in TGFbeta family signaling. Genesis 28:47-57.

Tsou K, Khachaturian H, Akil H, Watson SJ (1986) Immunocytochemical localization of pro-opiomelanocortin-derived peptides in adult rat spinal cord. Brain Res 378:28-35.

Unsicker K, Strelau J (2000) Functions of transforming growth factor-beta isoforms in the nervous system. Cues based on localization and experimental in vitro and in vivo evidence. Eur J Biochem 267:6972-6975.

Vierck Jr CJ (2006) Animal models of pain. In: Wall and Melzack's textbook of pain, Ed 5 (McMahon SB, Koltzenburg M), pp 175-186. London: Elsevier.

Vivien D, Ali C (2006) Transforming growth factor-beta signalling in brain disorders. Cytokine Growth Factor Rev 17:121-128.

Wrana JL, Attisano L, Wieser R, Ventura F, Massagué J (1994) Mechanism of activation of the TGF-beta receptor. Nature 370:341-347.

Wu CM, Lin MW, Cheng JT, Wang YM, Huang YW, Sun WZ, Lin CR (2004) Regulated, electroporation-mediated delivery of pro-opiomelanocortin gene suppresses chronic constriction injury-induced neuropathic pain in rats. Gene Ther 11:933-940.

Xu P, Van Slambrouck C, Berti-Mattera L, Hall AK (2005) Activin induces tactile allodynia and increases calcitonin gene-related peptide after peripheral inflammation. J Neurosci 25:9227-9235.

Yaksh TL, Gross KE, Li CH (1982) Studies on the intrathecal effect of betaendorphin in primate. Brain Res 241:261-269.

Yamaguchi K, Shirakabe K, Shibuya H, Irie K, Oishi I, Ueno N, Taniguchi T, Nishida E, Matsumoto K (1995) Identification of a member of the MAPKKK family as a potential mediator of TGF-beta signal transduction. Science 270:2008-2011.

Yan X, Lin Z, Chen F, Zhao X, Chen H, Ning Y, Chen YG (2009) Human BAMBI cooperates with Smad7 to inhibit TGF- $\beta$ signaling. J Biol Chem 284:30097-30104.

Zhang YE (2009) Non-Smad pathways in TGF-beta signaling. Cell Res 19:128-139.

Zhu W, Xu P, Cuascut FX, Hall AK, Oxford GS (2007) Activin acutely sensitizes dorsal root ganglion neurons and induces hyperalgesia via PKCmediated potentiation of transient receptor potential vanilloid I. J Neurosci 27:13770-13780.

Zimmermann M (1983) Ethical guidelines for investigations of experimental pain in conscious animals. Pain 16:109-110.

Zuzarte-Luís V, Montero JA, Rodriguez-León J, Merino R, Rodríguez-Rey JC, Hurlé JM (2004) A new role for BMP5 during limb development acting through the synergic activation of Smad and MAPK pathways. Dev Biol 272:39-52. 